\title{
Kansei analysis: Motorcycle of choice based on user preferences in the main commercial market area of Gedebage, Bandung
}

\author{
D. Yunidar \\ Telkom University, Bandung, Indonesia \\ A.Z.A. Majid \\ Universiti Sains Malaysia, Malaysia \\ T.Z. Muttaqien \\ Telkom University, Bandung, Indonesia
}

\begin{abstract}
Traders in the Gedebage market area often use a motorcycle as a vehicle to support their daily trading efforts. In dealing with the movement of goods with small dimensions, motorbikes are the most feasible modes of transportation to be used in the city of Bandung due to traffic conditions which often experience quite long and time-consuming traffic jams. The purpose of this paper is to present an overview to facilitate how to understand and build products that are consistent with the subjective factors of users in general. By using the Kansei Engineering approach to audit entities in the form of tangible products, and case studies in the form of motorcycle products that are used by traders in the commercial area of Gedebage Market, Bandung, in the end, this paper will provide an overview that can be used by product designers in translating subjective values that determine the user's decision in choosing a product.
\end{abstract}

Keywords: Kansei, motorcycle, user preferences

\section{INTRODUCTION}

Based on the 2019 population projection released by the Bandung Central Statistics Agency, Bandung has a population of more than 2.5 million people on workdays that almost doubles on the weekends due to domestic tourists visiting the city of Bandung. Thus it can be said that the city of Bandung is one of the busiest cities in Indonesia.

Judging from the administrative division map of the city of Bandung, the Gedebage area is the most extensive district in the city of Bandung which covers around $9.58 \mathrm{~km}^{2}$. With a population of around $40,120,000$ people and a growth rate of $0.01 \%$ per year, the Gedebage area is not the most populous region in the city of Bandung. This area is also passed by two main axes of the streets of Bandung, namely Jl. A.H Nasution, and Jl, Soekarno-Hatta, which makes it a strategic area and a crossing gate for fast access to enter the city of Bandung from the east and south.

Traders in the Gedebage market area often use motorbikes as vehicles to support their daily trading efforts. In dealing with the movement of goods with small dimensions, motorbikes are the most feasible mode of transportation to be used in the city of Bandung due to traffic conditions which often experience quite long and time-consuming traffic jams.

In buying a motorcycle, prospective users usually make their choices based on several common factors such as functional needs, price, engine capacity, maintenance costs, and after-sales prices, but often the potential users decide to buy the motorcycle based on non-technical factors and more on emotional factors such as the shape, color, or even the brand of the motorcycle. There is an interplay between technical factors and non-technical factors that make prospective users decide to choose and buy a particular motorcycle product, and this relationship is meant by subjective factors, where each potential user has a different subjective factor. 
This paper was made to present a framework to facilitate how to understand the user's subjective factors in general and how the subjective factors are formed.

\section{METHODOLOGY}

This research is conducted using two method approaches, namely a quantitative approach in the form of a generalization description of the results from the sampled data, and an explorative qualitative approach undertaken to gain a deep understanding of a motivation and reasons that need to be known.

This study was used "random sampling" of type "probability sampling" with the procedure "cluster random sampling", where all members of the population have the same opportunity to be selected as a sample.

Meanwhile, by using the "cluster random sampling" procedure the sampling technique can be carried out based on predetermined criteria, which in this case are motorcycle riders who work as traders, employees, students, and random citizens who are in four locations that are different, namely traditional markets, office areas, campus areas, and residential areas.

The sampling method with the probability sampling method is carried out on the consideration that the source of the sample in this study is homogeneous, where the samples are from the same demographic group (Suprapto 2001).

Based on the calculation, the number of samples used in this study is 40 respondents. This survey was conducted among people in public places, covering both genders (male and female) of various economic levels and ages.

There are six steps taken to audit a product using the Kansei approach in this case. The five steps are as follows:

1. Choice of participant groups

2. Collection of Kansei words

3. Data reduction methods for selection of Kansei words

4. Rating-scaled types used

5. Connecting the Kansei words to product properties

\section{ANALYSIS AND RESULTS}

From the data obtained through questionnaires and short interviews with respondents in the Gedebage traditional market are, it can be concluded that the results are as follows.

Table 1 indicates that the majority of traders in the area of Gedebage's traditional market feel that family values, social values, and material values are very important in their lives, especially religious values.

Table 2 indicates that the majority of traders in the area of Gedebage's traditional market are the type of people who are realistic in their attitude.

Table 1. Respondents respond to section A (life values) in Gedebage traditional market area.

\begin{tabular}{lllllll}
\hline & N & Range & Minimum & Maximum & Mean & Std. Deviation \\
\hline Section A1 & 50 & 1 & 2 & 5 & 4.48 & .863 \\
Section A2 & 50 & 1 & 4 & 5 & 4.66 & .479 \\
Section A3 & 50 & 4 & 1 & 5 & 4.28 & .671 \\
Section A4 & 50 & 1 & 4 & 5 & 4.92 & .274 \\
Section A5 & 50 & 3 & 2 & 5 & 4.28 & .784 \\
Valid N (listwise) & 50 & & & & & \\
\hline
\end{tabular}


Table 2. Respondents respond to section B (attitude) in Gedebage's traditional market area.

\begin{tabular}{lllllll}
\hline & N & Range & Minimum & Maximum & Mean & Std. Deviation \\
\hline Section B1 & 50 & 3 & 2 & 5 & 3.86 & .857 \\
Section B2 & 50 & 3 & 2 & 5 & 3.92 & .724 \\
Section B3 & 50 & 3 & 2 & 5 & 3.04 & .605 \\
Section B4 & 50 & 3 & 2 & 5 & 3.96 & .832 \\
Section B5 & 50 & 4 & 1 & 5 & 2.26 & 1.291 \\
Valid N (listwise) & 50 & & & & & \\
\hline
\end{tabular}

Table 3. Respondents respond to section C (interest) in Gedebage's traditional market area.

\begin{tabular}{lllllll}
\hline & N & Range & Minimum & Maximum & Mean & Std. Deviation \\
\hline Section C1 & 50 & 4 & 1 & 5 & 4.20 & .808 \\
Section C2 & 50 & 4 & 1 & 5 & 3.00 & 1.370 \\
Section C3 & 50 & 4 & 1 & 5 & 3.36 & 1.241 \\
Section C4 & 50 & 4 & 1 & 5 & 2.28 & 1.230 \\
Section C5 & 50 & 4 & 1 & 5 & 3.52 & 1.446 \\
Valid N (listwise) & 50 & & & & & \\
\hline
\end{tabular}

Table 4. Respondents respond to section D (lifestyle) in Gedebage's traditional market area.

\begin{tabular}{lllllll}
\hline & N & Range & Minimum & Maximum & Mean & Std. Deviation \\
\hline Section D1 & 50 & 4 & 1 & 5 & 3.48 & 1.282 \\
Section D2 & 50 & 4 & 1 & 5 & .04 & 1.384 \\
Section D3 & 50 & 4 & 1 & 5 & 3.08 & 1.353 \\
Section D4 & 50 & 4 & 1 & 5 & 2.30 & 1.182 \\
Section D5 & 50 & 4 & 1 & 5 & 3.54 & 1.249 \\
Valid N (listwise) & 50 & & & & & \\
\hline
\end{tabular}

Table 5. Kansei words that have been collected.

\begin{tabular}{lll}
\hline Ambiance & Fit & Sense of materials \\
Design image & Shape & New combination \\
Color & Functionality \& convenience & Unexpected application \\
\hline
\end{tabular}

Table 3 indicates that the majority of traders in the area of Gedebage traditional market are the type of people who are pennywise in the way they spend their money.

Table 4 indicates that the majority of traders in the area of Gedebage's traditional market are a simple type of people with regard to their lifestyle.

In the step of collection of Kansei words, Kansei engineering type I is used to determine consumer preferences for product design elements. At the stage of collecting Kansei's words, nine words are consisting of adjectives and product functions as the first global Kansei words. Table 5 shows a set of Kansei words that has been collected.

Results of the data reduction step, the Kansei words are then grouped based on similarity in the context of their meaning, as shown in Table 6. This stage produces three major groups of Kansei words.

Of the three groups formed, each group is given a naming label and sorted by the level of scale assessment of technical, physical, and emotional aspects, as shown in Table 7. In this stage the names for each group are summarized as follows: emotional factors, interface factors, and basic factors. 
Table 6. Kansei words grouped based on similarity in the context of their meaning.

\begin{tabular}{|c|c|c|c|c|}
\hline $\begin{array}{l}\text { Ambiance } \\
\text { Color } \\
\text { New combination }\end{array}$ & Fit & Shape & Functionality \& convenience & $\begin{array}{l}\text { Design image } \\
\text { Sense of material } \\
\text { Unexpected application }\end{array}$ \\
\hline
\end{tabular}

Table 7. Labeling the Kansei words grouped.

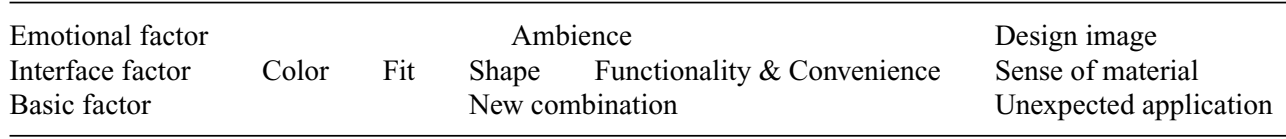

Data resulting from the "Rating-scaled types used" stage yields the arrangement in Figure 1. Arrangement formed from this stage can be an indication of the stages of prospective users in making decisions to choose or buy motorcycle products offered in the market.

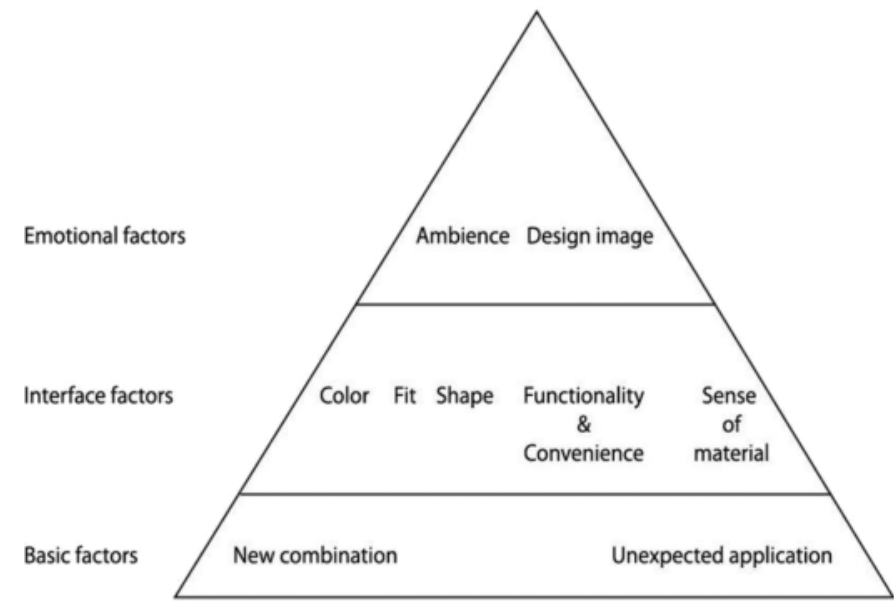

Figure 1. Grouping factors that arise from the participants' chosen opinions.

\section{CONCLUSION}

In Figure 2, it can be seen that the three groups of factors created influence each other in creating/forming subjective factors of potential users in choosing and deciding to buy certain motorcycle products. Basic factors are usually the most common things that prospective users consider in making their choices, but after the basic factors are felt to be appropriate then the next consideration is interface factors which include the visual appearance of the product such as color, fit, shape, functionality \& convenience, and sense of material, whereas emotional factors are very personal in nature and determine the final decision of the prospective user to buy a product even though under certain conditions these emotional factors may not be present in the consideration of prospective users in deciding to buy a particular product. These three factors influence each other and form subjective factors for potential users of the product.

When prospective users discuss a motorcycle model/type, what they will pay attention to and ask first is "what advantages does it offer?" Or "what is the novelty offered by that model/type compared to others?" This is a very basic and hallo-point thing, and if the prospective user feels/finds something interesting in this level then the process of determining the choice will continue to other 


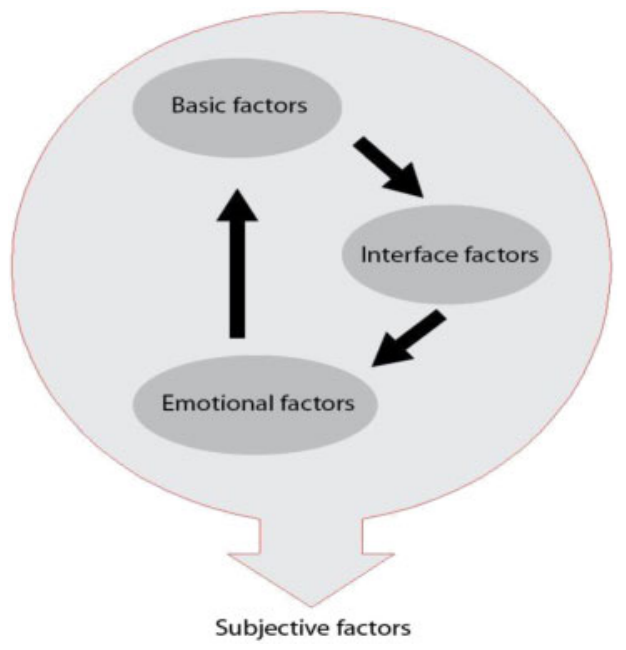

Figure 2. Kansei words group relations in the formation of subjective factors.

factors. But for some prospective users and in particular conditions this also could be enough and then they will decide to buy it or not buy it.

In the next stage, prospective users will look for whether a particular model/type has the color, fit, shape, functionality \& convenience, and several models/types of motorcycle products on the market. Specifically, for the sense of material prospective users will see whether the products are different from one another in terms of finishing material, and this sense of material will determine that one product is made of higher quality compared to rival products in the view of prospective users.

In the most relaxed conditions where prospective users have more free time and funds, the consideration for choosing and buying a motorcycle product will go to the level of emotional factors, where potential buyers make their choice on the ambiance factors and image design of a motorcycle-like product that will be chosen.

\section{REFERENCES}

Goebert, B. and Rosenthal, H. M. 2001. Beyond listening: Learning the secret language of focus groups. New York: J. Wiley. URL for chapter 1: Listening 101: The Value of Focus Groups. http//www.wileyeurope.com/cda/cover/0,0471395625\%7Cexcerpt,00.pdf.

Kunifuji, S. 2013. A Japanese problem-solving approach: the KJ-Ho method. Proceedings of KICSS'2013, pp. 333-338. Progress \& Business Publishers, Kraków.

Levy, P., Lee, S., and Yamanaka, T. 2007. On Kansei and Kansei Design a Description of Japanese Design Approach. Proceedings of the 2nd World Conference on Design Research, 1-18.

Norman, D. A. 2004. Emotional Design: Why we love (or hate) everyday things. New York. Basic Books.

Nagasawa, S. 2002. Kansei and Business, Kansei Engineering International Journal, 3:2-12.

Phua, S. J., Keong Ng, W., Liu, H., Song, B., and Li, X. 2007. A Rule Mining Approach To Emotional Design In Mass Customization. International Conference on Engineering Design. ICED.

Schutte, S., Eklund, J., Ishihara, S., and Nagamichi, M. 2008. Affective meaning: The Kansei Engineering Approach. In: Schifferstein, H.N.J., and Hekkert, P. (Editors). 2008. Product Experience. Elsevier.

Scupin, R. 1997. The KJ Method: A Technique for Analyzing Data Derived from Japanese Ethnology. Human Organization, 56(2):233-237.

Tama, I. P., Azlia, W., and Hardiningtyas, D. 2015. Development of Customer-Oriented Product Design using Kansei Engineering and Kano Model: Case Study of Ceramic Souvenir. Procedia Manufacturing, 4(Iess):328-335. 